\title{
PANCASILA DASAR NEGARA BUKAN PILAR (KOMUNITAS PANCASILA DASAR NKRI BUKAN PILAR)
}

\author{
K.R.A.P.Eri Ratmanto ${ }^{1}$ \\ Alumni Teknik Perminyakan UPN Veteran Yogyakarta \\ Email: juliusseri@yahoo.com
}

\begin{abstract}
ABSTRAK
Kondisi masyarakat sekarang ini mengalami kebimbangan karena terdapat kelompok masyarakat yang memberikan pernyataan bahwa Pancasila adalah bagian dari 4 pilar. Menurut UUD 1945, dikatakan bahwa Pancasila adalah dasar Negara. Persoalan yang terjadi terjadi perubahan makna dan pemahaman Pancasila menjadi 4 pilar kenegaraan. Tulisan ini akan menganalisis perubahan dan perbedaan pemahaman tentang Pancasila di masyarakat. Untuk mengembalikan pengertian yang mendasar bahwa Pancasila dasar Negara Republik Indonesia, maka diperlukan berbagai macam gerakan. Metode yang digunakan dalam penelitian ini menggunakan pendekatan kualitatif, interpretasi, observasi, dan wawancara. Hasil ditemukan dalam kajian ini menunjukkan terjadi perbedaan pemahaman di masyarakat tentang memahami Pancasila sebagai pilar atau dasar Negara. Perbedaan ini terjadi karena ada sosialisasi yang dilakukan yang menyesatkan masyarakat dengan menyebut Pancasila sebagai bagian dari salah satu pilar kenegaraan.
\end{abstract}

Kata Kunci: Pancasila, bukan pilar, dasar, Negara.

\begin{abstract}
The current condition of society is experiencing confusion because there are groups of people who state that Pancasila is part of the 4 pillars. According to the 1945 Constitution, it is said that Pancasila is the basis of the State. The problem that occurs is a change in the meaning and understanding of Pancasila into the 4 pillars of the state. This paper will analyze changes and differences in understanding about Pancasila in society. To restore the basic understanding that Pancasila is the basis of the Republic of Indonesia, various kinds of movements are needed. The method used in this study uses a qualitative approach, interpretation, observation, and interviews. The results found in this study indicate that there is a difference in understanding in society about understanding Pancasila as a pillar or basis of the State. This difference occurs because there has been socialization that has been misleading the public by calling Pancasila as part of one of the pillars of statehood.
\end{abstract}

Keywors: Pancasila, not pillar, basic, state. 


\section{PENDAHULUAN}

Generasi sekitar usia di atas 45 atau 50 an ketika masih sekolah dasar diajarkan oleh para gurunya bahwa Pancasila adalah dasar Negara. Namun, 10 tahun terakhir ini, muncul gagasan atau program Pancasila menjadi salah satu pilar kebangsaan yang dilakukan oleh MPR RI. Kegelisahan yang mendasar bagi masyarakat bahwa Pancasila adalah dasar dan pondasi kemudian disosialisasikan menjadi salah satu pilar. Dalam berbagai catatan dan perjalanan penulis yang melakukan observasi dan diskusi dengan berbagai pihak menemukan bahwa banyak masyarakat juga gelisah dengan adanya sosialisasi 4 pilar. Bukti kegelisahan ini semakin nyata dengan munculnya papan dari semen bertuliskan Empat Pilar yang di bawahnya terdiri atas Pancasila, UUD 1945, Kebhinekaan, dan NKRI. Papan dari semen tersebut terletak di dusun Ngawen, Gamping, Sleman Yogyakarta yang dibuat salah satu tokoh masyarakat di dusun tersebut. Sebagaimana pada gambar di bawah ini.

Gambar.1.1. Papan Semen bertulis Empat Pilar

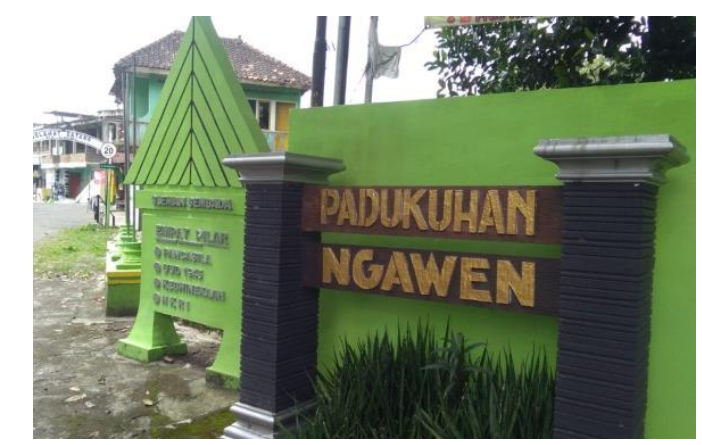

Sumber: foto pribadi penulis, diambil, 7 Februari 2021.

Gambar 1.1. di atas menunjukkan bahwa kondisi masyarakat dalam memahami Pancasila semakin mengalami reduksi karena dampak dari sosialisasi 4 Pilar yang dibuat oleh MPR RI. Kegelisahan ini juga pernah dilakukan oleh masyarakat yang lainnya dengan melakukan uji materiil terhadap Undang Undang yang mendasari sosialisasi 4 pilar di Mahkamah Konstitusi pada tahun 2013-2014. Hasil dari uji materiil tersebut menyatakan bahwa empat pilar berbangsa dan bernegara bertentangan dengan Undang Undang Dasar 1945 dan tidak memiliki kekuatan yang mengikat. Namun, program sosialisasi 4 pilar tetap berjalan. Pada Kongres Pancasila yang dilakukan di UGM juga muncul berbagai kritik atas sosialisasi 4 pilar ini. Kemudian pemerintahan berganti sampai pada masa pemerintahan presiden Jokowi, kegiatan sosialisasi 4 pilar MPR RI ini masih berjalan dengan menyebut 4 pilar yang terdiri atas Pancasila, UUD 1945, NKRI, dan Bhinneka Tunggal Ika.

Perdebatan tentang adanya 4 pilar MPR RI ini muncul menjadi dua kubu. Kubu pertama setuju dengan adanya 4 pilar MPR RI karena dianggap mengingatkan masyarakat pentingnya pilar pilar berbangsa dan bernegara. Pada aspek yang lain muncul berbagai macam penolakkan karena penggunaan istilah untuk program sosialisasi 4 pilar tidak tepat atau kontraproduktif karena menganggap Pancasila sebagai bagian dari pilar, UUD 1945 sebagai bagian dari pilar, NKRI sebagai bagian dari pilar, dan Bhinneka Tunggal Ika sebagai pilar.

Pada masa pemerintahan Jokowi sejak tahun 2017 telah berdiri Unit Kerja Presiden Pembinaan Ideologi Pancasila (UKP-PIP) yang bertujuan untuk meneguhkan nilai nilai Pancasila masih belum bisa maksimal berjalan karena ada program yang berlainan yang dibuat oleh politisi di MPR RI dengan menyebut 4 pilar MPR RI. Pada tahun 2018, UKP PIP berganti nama menjadi Badan Pembinaan Ideologi Pancasila (BPIP) Republik Indonesia, kegiatan 4 pilar masih saja berjalan.

Dalam kondisi ini, masyarakat kebingungan terhadap perilaku dan kebijakan pemerintah atau politisi yang 
melakukan program sosialisasi tentang nilai nilai kebangsaan namun berbeda isinya. Kelompok masyarakat mulai gelisah dan melakukan gerakan untuk meluruskan program sosialisasi 4 pilar yang menyebut Pancasila, UUD 1945, NKRI, dan Bhinneka Tunggal Ika dengan gerakan Komunitas Pancasila dasar negara NKRI bukan pilar. Kelompok ini melakukan berbagai kegiatan dengan cara sosialisasi program Pancasila sebagai dasar Negara bukan Pilar melalui booklet, banner, mug, stiker, dan spanduk yang diperkenalkan kepada masyarakat. Bahkan kegiatan di media sosial dilakukan sampai membuat surat terbuka kepada MPR RI dengan tembusan berbagai macam instansi terkait tahun 2020, dan menulis surat pembaca kepada redaksi Koran kompas, yang dimuat tanggal 7 September 2020. Isi dari surat redaksi itu menyampaikan ketidaksetujuan istilah 4 pilar MPR RI yang dilakukan oleh penyelenggara negara dalam hal ini MPR RI karena Pancasila tidak pernah dikenal sebagai 4 pilar apalagi bagian dari pilar pilar MPR RI. Dalam sejarah bangsa Indonesia UUD 1945, Bhinneka Tunggal Ika, dan NKRI tidak pernah dikenal sebagai pilar.

Dalam perjalanan, semakin hari banyak masyarakat semakin tersadarkan dan bertambah pengetahuannya bahwa Pancasila adalah dasar Negara dan bukan pilar. Selama memberikan pemahaman hal tersebut banyak kendala dan tantangan. Ada kelompok yang mendukung dan tidak mendukung. Dalam kegiatan sosialisasi 4 pilar kebangsaan yang dilakukan MPR RI disebut 4 pilar MPR RI di Yogyakarta ada yang menanyakan posisi pilar pilar tersebut. Namun, program sosialisasi 4 pilar MPR RI masih berjalan dengan kelompok sasaran yang ada di masyarakat.

Gerakan masyarakat untuk melawan 4 pilar ini digagas oleh masyarakat dengan mengembalikan pengertian awal Pancasila sesuai dengan Undang Undang Dasar 1945 yaitu Pancasila sebagai dasar NKRI bukan pilar. Dalam dunia pendidikan dasar sampai menengah ke atas menjadi kebingungan terkait dengan adanya program sosialisasi 4 pilar MPR RI. Kebingungan yang muncul apakah Pancasila tetap menjadi dasar Negara atau bagian dari pilar kebangsaan atau pilar milik MPR RI. Masyarakat mengalami sikap apatisme (ketidakpedulian) dengan adanya program sosialisasi 4 pilar MPR RI. Pada kalangan pejabat pun, pada dasarnya ada yang kelompok pro dan kontra terhadap program sosialisasi 4 pilar MPR RI baik melalui cetak buku dan berbagai macam media. Terdapat dua model sosialisasi yaitu Pancasila sebagai bagian dari 4 pilar kebangsaan dan model Pancasila sebagai konsensus dasar kehidupan berbangsa dan bernegara. Hal ini berdampak pada biaya yang tidak sedikit, apakah proyek ini bermanfaat dan dikembalikan pada elit politik agar biaya yang keluar juga tidak menimbulkan beban anggaran Negara dan digunakan dengan cara yang lebih bermanfaat. Gerakan perlawanan dilakukan oleh masyarakat membuat group WA untuk mendiskusikan tentang persoalan sosialisasi 4 pilar yang menganggu pemahaman dan pengetahuan masyarakat. Group WA ini terdiri atas dari kalangan akademisi, masyarakat, dan mahasiswa.

Penelitian ini akan menganalisis dan mendeskripsikan tentang bagaimana kegiatan masyarakat untuk melakukan penolakkan terhadap sosialisasi 4 pilar. Dasar dasar apa saja yang diajukan oleh masyarakat dalam menolak program sosialisasi 4 pilar MPR RI. Sampai sejauh mana masyarakat melakukan advokasi dan mendapatkan tanggapan dari penyelenggara Negara dalam hal ini MPR RI. 


\section{METODE}

Metode yang digunakan dalam penelitian ini menggunakan pendekatan kualitatif. Data yang diperoleh untuk menganalisis persoalan Pancasila dasar negara bukan pilar dari dokumen gerakan komunitas Pancasila dasar negara NKRI dan bukan pilar, studi pustaka, observasi, dan wawancara yang dilakukan melalui media daring secara khusus group wa. Data tersebut kemudian dianalisis secara kritis dan interpretatif dari peneliti.

\section{HASIL DAN PEMBAHASAN}

\section{Konsep Pancasila di masyarakat}

Masyarakat memandang bahwa Pancasila merupakan dasar Negara Indonesia. Dalam aspek historis dan sosiologis menunjukkan bahwa konsep masyarakat tentang Pancasila adalah dasar negara. Kemudian dalam konteks kekinian, masyarakat yang selama ini mendapatkan sosialisasi 4 pilar memahami Pancasila sebagai dasar negara dan sebagai pilar negara. jadi ada dua pemahaman yang muncul terjadi di masyarakat. Dalam konteks kuantitatif memang belum ada penelitian berapa jumlah kelompok masyarakat atau anggota masyarakat yang menyebut pilar dan bukan pilar. Untuk generasi muda semakin era milenial memahami Pancasila semakin menjauh.

Dalam diskusi pada group wa berjudul Pancasila dasar NKRI bukan pilar yang terdiri dari berbagai kelompok masyarakat. Muncul berbagai argumentasi tentang Pancasila terpecah menjadi dua kelompok. Kelompok pertama, tetap mendukung 4 pilar dengan berbagai pemahaman yang dimiliki dan kelompok kelompok kedua yang berbeda pemahaman tentang 4 pilar karena menyakini Pancasila sebagai dasar negara bukan salah satu bagian dari pilar. Bahkan ada yang mengusulkan 4 pilar dirubah menjadi 4 konsensus bangsa. (sumber: group wa, Pancasila dasar negara bukan pilar, 7 Februari 2021).

Berdasarkan dari pengalaman penulis dalam mengumpulkan berbagai tokoh kerajaan di nusantara. Para bangsawan tetap menyakini bahwa Pancasila sebagai dasar NKRI bukan pilar (Sumber: penggalian informasi ini dan jajak pendapat dimulai dari tahun 2020 sampai sekarang).

\section{Gerakan Pancasila Dasar Negara bukan Pilar}

Gerakan ini muncul sejak tahun 2009 namun masih sepotong-sepotong. Gerakan ini mulai muncul kembali ketika bertemu dengan salah satu akademisi yang menulis kritik atas 4 pilar pada tahun 2019 sampai sekarang. Gerakan Pancasila Dasar Negara bukan Pilar mulai mengembangkan berbagai program dan kegiatan untuk memberikan edukasi kepada masyarakat tentang pentingnya Pancasila dasar Negara bukan pilar. Gerakan ini lahir dari semangat dan kesadaran tokoh masyarakat untuk membangun daya kritis dan nalar bagi masyarakat pentingnya kembali kepada Pancasila bukan pilar. Proses pilarisasi ini terjadi karena elit politik masih bingung mencari bentuk melakukan penanaman nilai nilai Pancasila. Bahkan di dunia akademik diteliti juga sebab dan fenomena 4 pilar tersebut dengan berbagai macam kesalahan filosofi, kesalahan semantik, dan kesalahan yuridis dalam penggunaan bahasa 4 pilar. 
Upaya untuk mengembalikan Pancasila pada pengertian dan konsep dasar secara terus menerus dilakukan oleh masyarakat dengan melakukan pendekatan kultural dan bergerilya mencari pemahaman yang sama melalui diskusi. Surat terbuka yang pernah dibuat untuk menjadi upaya penjelasan kepada elit politik yang dikirimkan di media Koran Kompas juga dilakukan. Pengalaman dari berbagai diskusi melalui WA group yang dibangun oleh kelompok pergerakan menumbuhkan ingatan masa lalu tentang penataran P4. Diharapkan semacam penataran P4 dan kurikulum Pancasila untuk lebih diperhatikan dan ditambah lagi.

\section{Gambar 1.1 Gerakan Pancasila Dasar Negara bukan Pilar}
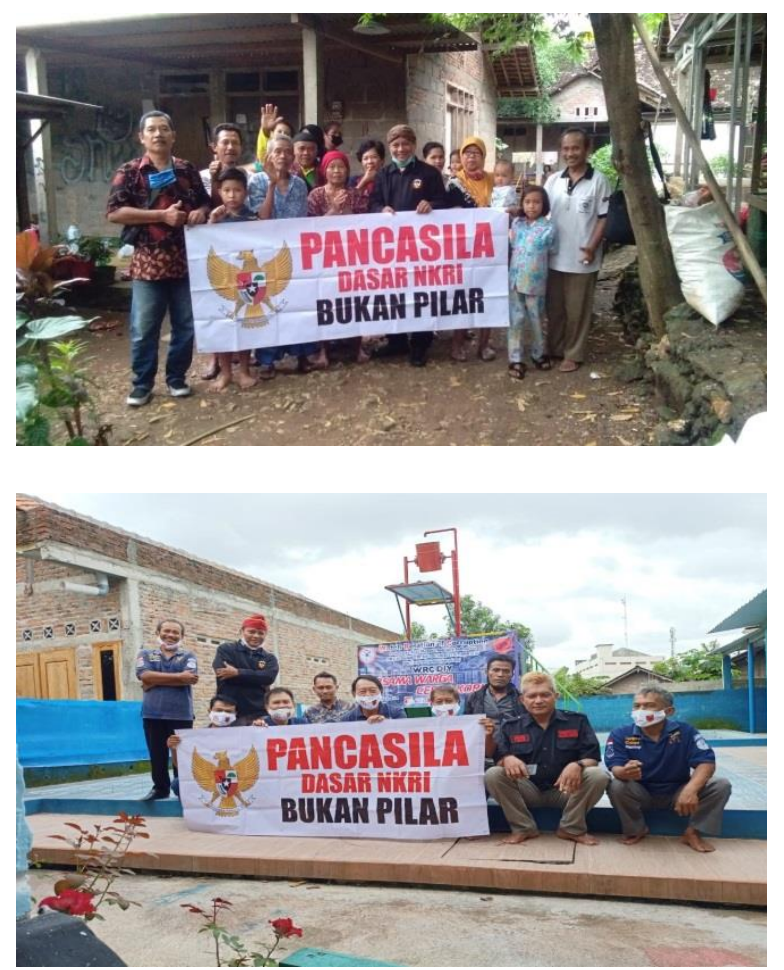

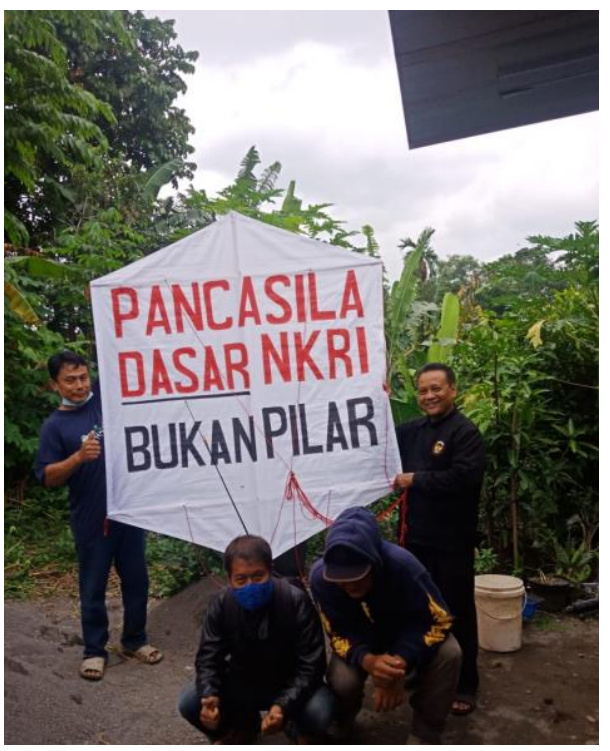

Sumber: dokumen pribadi penulis, 2021.

Muatan-muatan Pancasila dan pengalaman Pancasila termasuk pengenalan lagu lagu kebangsaan dapat diupayakan dan dilakukan secara terus menerus. Sehingga pengaruh pengaruh dari pendidikan luar Indonesia tidak terlalu banyak termasuk pola pendidikan yang ada di Indonesia. Hal ini dilakukan karena jika Pancasila diganti dengan istilah lain menjadi pilar maka paham paham yang lain akan mengganti dengan berbagai ideologi lain termasuk sekarang banyak partai partai politik sudah merubah asas dan prinsip partai menjadi ideologi yang lain. Saat ini, MPR RI masih menganggap Pancasila sebagai pilar untuk MPR RI saja.

Pada era zaman dulu banyak bangunan yang memperlihatkan Pancasila dasar Negara beserta sila silanya. Namun sekarang muncul tugu yang disebut 4 pilar kebangsaan. Hal ini dapat ditemukan di desa Ngawen, Sleman. Gerakan ini melakukan berbagai penolakkan dengan cara membuat mug Pancasila dasar Negara bukan Pilar.

Kasus Masyarakat suku Kodi Sumba, Nusa Tenggara Timur (NTT) 
memberikan pengalaman dan penjelasan bahwa ketika era presiden Soekarno dan orde baru bahwa Pancasila merupakan dasar negara. Istilah Pancasila sebagai pilar tidak dikenal di dalam masyarakat yang dialami sekarang. Namun perkembangan ini menjadi menarik karena Pancasila dirubah menjadi pilar. (Sumber: wawancara Marcel, Suku Kodi, Sumba Barat Daya, Nusa Tenggara Timur, 2 Februari 2021, 14:00).

Pancasila sebagai fondasi/dasar. Jika fondasi tidak kuat berarti lemah pilar pilar yang di atasnya. Fondasi ini mendasari sebuah bangunan atau pilar pilar yang ada apabila dianologkan sebagai wujud bangunan. Persoalan ini sangat penting jika pemahaman yang salah maka akan berdampak pada tindakan dan perilaku masyarakat akan menjadi seenaknya (sumber: wawancara dengan responden dari Salatiga, aktivis Rema, 2 Februari 2021 pkl.14:00).

Metafora yang selama ini berkembang dalam menjelaskan dan meluruskan tentang Pancasila juga dilakukan oleh salah satu tokoh pendeta beragama Hindu dengan membuat sketsa gambar tentang imajinasi kehidupan berbangsa dan bernegara khususnya dalam perdebatan 4 pilar tersebut. Berikut ini bagan yang dibuat oleh salah satu narasumber.

Bagan 1.3. sketsa metafora bangunan

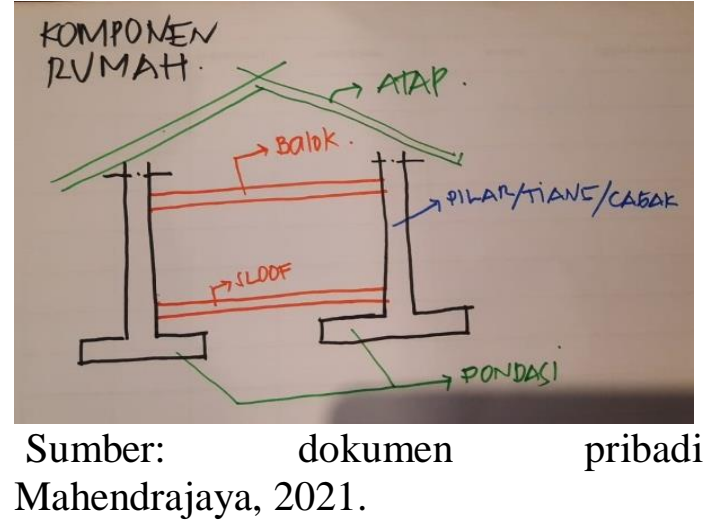

Penjelasan yang dapat disampaikan dalam bagan sketsa ini menyampaikan bahwa kalau fondasi tidak kuat maka yang lainnya akan roboh. Dalam metafora di atas menunjukkan bahwa ada pondasi atau Dasar, kemudian ada sloof, kemudian ada pilar atau cagak atau tiang, kemudian ada balok lagi untuk menahan kekuatan baru terakhir atap. Dalam membangun rumah pondasi itu sudah dihitung berdasarkan beban atau muatan yang ada di atasnya, baik itu beban sloof yaitu penahan beban akibat dari beban pilar balok dan atap, kemudian ada pilar yg bertugas untuk menahan beban dari balok, atap dan beban pilar itu sendiri.

Jadi jika pondasi dasar tidak kuat maka bangunan yang di atasnya pasti runtuh. Kalau pilar atau jagak atau kolom tidak kuat maka masih bisa diperkuat dengan sistem retrofitting. Kesimpulannya pondasi atau dasar itu berbeda dgn pilar (Wawancara dengan N.N Mahendrajaya, 7 Februari 2021, pkl.14.50).

Proses pembentukan negara bangsa masih harus terus menerus dilakukan untuk menyadarkan dan menggerakan semua elemen bangsa akan memiliki jiwa dan kesadaran yang utuh tentang arti penting Pancasila dalam kehidupan berbangsa dan bernegara. Upaya penyimpangan Pancasila dengan membalikkan atau mengganti istilah Pancasila sebagai pilar atau sebagai istilah yang lain bukan pada tempatnya menjadi salah satu bentuk hilangnya rasa nasionalisme di kalangan elit bangsa ini. Tulisan ini menjadi bagian dari catatan perjalanan penulis dalam melakukan observasi, wawancara, dan diskusi terhadap sejumlah kelompok masyarakat untuk melihat cara pandang dan 
perubahan perubahan yang terjadi di masyarakat dalam memahami Pancasila.

\section{SIMPULAN}

Pergerakan ini masih perlu proses panjang untuk menyadarkan masyarakat tentang Pancasila dasar Negara bukan pilar. Upaya untuk mengembalikan pengertian Pancasila dasar Negara bukan bagian dari 4 pilar karena MPR RI melalui program sosialisasi 4 pilar ini sudah berjalan beberapa tahun dengan anggaran yang luar biasa besarnya.

\section{UCAPAN TERIMA KASIH}

Puji Syukur dipanjatkan kepada Tuhan Yang Maha Esa, senantiasa membimbing dan memberikan kekuatan batin kepada penulis didalam perjuangan mengembalikan pengertian dan pemahaman Pancasila sebagai Dasar NKRI bukan sebagai salah satu pilar.

Tidak lupa pula diucapkan terima kasih kepada para pejuang Pancasila, para guru,dosen, Pusat Studi Pancasila dan masyarakat yang menyetujui Pancasila sebagai salah satu Pilar MPR RI maupun yang tidak menyetujui Pancasila sebagai salah satu Pilar MPR RI, melainkan Tetap konsisten mengatakan bahwa Pancasila Dasar NKRI bukan pilar.

Kepada Komisi Pemberantasan Korupsi Republik Indonesia, diucapkan terima kasih telah menanggapi Surat Terbuka penulis tertanggal 03 Juli 2020 yang dijawab tanggal 7 September 2020 ditandatangani atas nama Pimpinan Deputi Bidang Pengawasan Internal dan Pengaduan Masyarakat.

Penulis juga mengucapkan terima kasih kepada Redaksi Kompas, yang telah memuat
Pancasila Dasar Negara pada tanggal 7 September 2020.

Kepada mas Lobo (PSP UPN Veteran Yogyakarta) dan mas Hastangka, yang terus menerus membimbing penulis seorang berlatar belakang teknik, bisa memahami Pancasila dari sisi Filsafat.

Ucapan terima kasih penulis ditujukan juga kepada komunitas di WA Group Pancasila Dasar NKRI bukan pilar, dengan semangat dan menjaga Pancasila sebagai Dasar NKRI bukan Pilar, tiap hari senantiasa berdiskusi dan sharing apa yang terjadi di daerahnya dari Sabang sampai Merauke, dari Miangas sampai Rote.

\section{TENTANG PENULIS}

K.R.A.P. Eri Ratmanto adalah alumni Teknik Perminyakan UPN Veteran Yogyakarta Angkatan 1988. Aktif di Kekerabatan Kerajaan sebagai Sentana dalem Karaton Kasunanan Surakarta Hadiningrat, di bidang budaya, lingkungan hidup, Perpustakaan dan Museum.

Sekarang Aktif sebagai Sekretaris Dewan Koperasi Indonesia Wilayah DIY (Hasil Muswil 15 Oktober 2020).

Ormas LSM yang masih di kelola antara lain sebagai Penasehat Gerakan Anti Narkoba Nasional di DIY, Penasehat Lembaga Perlindungan konsumen Nusantara Satu, Penasehat WRC (Anti Korupsi). Sebagai Ketua Gerakan Batik Anti Terorisme (Youtobe/gogle: Batik Anti Terorisme)

Bersama masyarakat dan komponen bangsa memperjuangkan di Komunitas Pancasila Dasar NKRI bukan pilar.

Sebagai seorang Pramuka, senantiasa memberikan semangat Bela Negara kepada generasi milenial. Kegiatan yang dilakukan antara lain pelayaran Lintas Nusantara bersama Pramuka Saka Bahari Nasional 
memakai Kapal Perang milik Angkatan Laut, dengan nama kegiatan PELANTARA. Sebagai anggota Kehormatan Pembela Martabat Bangsa melalui perlawanan Veteran di NTT melawan Calo dan Veteran palsu di NTT. (Youtube: Veteran Palsu. NTT)

Berjuang di Perbatasan NTT-Timles, di pengungsian masyarakat Timtim pro NKRI, di Sukabitetek, Raimanuk, Belu, NTT (Youtube: Kak Kangjeng eri bersama anak anak pengungsi Timtim pro NKRI di Sukabitetek)

\section{DAFTAR PUSTAKA}

- Hastangka, Armawi, Kaelan. 2018. Analisis Putusan Mahkamah Konstitusi Nomor 100/PUU-XI/2013 tentang Pembatalan Frasa Empat Pilar Kehidupan Berbangsa dan Bernegara, Mimbar Hukum, Vol.30 Nomor 2 Juni 2018. Hal.230-245.
- Putusan Mahkamah Konstitusi Nomor 100/PUU-XI/2013.

- Wawancara responden dari Suku Kodi, Sumba Barat, NTT, 7 Februari 2021 pkl.14:00.

- Wawancara dengan responden dari Salatiga, aktivis Rema, 2 Februari 2021 pkl.14:00.

- Wawancara dengan N.N.Mahendrajaya, 7 Februari 2021, pkl.14.50).

- Wawancara dengan salah satu Datuk dari Pagaruyuang, Sumatera Barat. 7 Februari 2021.

- Wawancara dengan Pak Dukuh Santan, Pajangan, Bantul,DIY di Bantul,7 Februari 2021

- Wawancara dan diskusi dengan salah satu mahasiswa S2 Hukum UII, asal Papua, rentang waktu tahun 2020.

- Wawancara dengan Tokoh Veteran pembela martabat bangsa dari NTT, Rentang waktu 2020. 